\title{
Association between maternal serum 25-hydroxyvitamin D level and pregnancy and neonatal outcomes: systematic review and meta-analysis of observational studies
}

\author{
(c) $\begin{gathered}\text { (1) (8) } \\ \text { ay }\end{gathered}$
}

Fariba Aghajafari assistant professor of family medicine ${ }^{12}$, Tharsiya Nagulesapillai data analyst ${ }^{1}$, Paul E Ronksley doctoral candidate ${ }^{13}$, Suzanne C Tough professor of paediatrics ${ }^{14}$, Maeve O'Beirne associate professor of family medicine ${ }^{2}$, Doreen M Rabi assistant professor of medicine ${ }^{135}$

${ }^{1}$ Department of Community Health Sciences, University of Calgary, Calgary, Alberta T2N 4N1, Canada; ${ }^{2}$ Department of Family Medicine, University of Calgary, Canada; ${ }^{3}$ Calgary Institute for Population and Public Health, University of Calgary, Canada; ${ }^{4}$ Department of Paediatrics, University of Calgary, Canada; ${ }^{5}$ Department of Medicine, University of Calgary, Canada

\begin{abstract}
Objective To assess the effect of 25-hydroxyvitamin D (25-OHD) levels on pregnancy outcomes and birth variables.

Design Systematic review and meta-analysis.

Data sources Medline (1966 to August 2012), PubMed (2008 to August 2012), Embase (1980 to August 2012), CINAHL (1981 to August 2012), the Cochrane database of systematic reviews, and the Cochrane database of registered clinical trials.

Study selection Studies reporting on the association between serum 25-OHD levels during pregnancy and the outcomes of interest (pre-eclampsia, gestational diabetes, bacterial vaginosis, caesarean section, small for gestational age infants, birth weight, birth length, and head circumference).

Data extraction Two authors independently extracted data from original research articles, including key indicators of study quality. We pooled the most adjusted odds ratios and weighted mean differences. Associations were tested in subgroups representing different patient characteristics and study quality.

Results 3357 studies were identified and reviewed for eligibility. 31 eligible studies were included in the final analysis. Insufficient serum levels of 25-OHD were associated with gestational diabetes (pooled odds ratio $1.49,95 \%$ confidence interval 1.18 to 1.89 ), pre-eclampsia $(1.79,1.25$ to 2.58$)$, and small for gestational age infants $(1.85,1.52$ to 2.26). Pregnant women with low serum $25-\mathrm{OHD}$ levels had an increased risk of bacterial vaginosis and low birthweight infants but not delivery by caesarean section.
\end{abstract}

Conclusion Vitamin D insufficiency is associated with an increased risk of gestational diabetes, pre-eclampsia, and small for gestational age infants. Pregnant women with low 25-OHD levels had an increased risk of bacterial vaginosis and lower birth weight infants, but not delivery by caesarean section.

\section{Introduction}

Vitamin D insufficiency has been associated with several adverse health outcomes, including pregnancy outcomes, and is increasingly recognised as a public health concern. Observational data suggest a link between low 25-hydroxyvitamin D (25-OHD) levels - the best measure of vitamin D status in humans - and an increased risk of adverse pregnancy outcomes such as gestational diabetes, pre-eclampsia, infections, caesarean section, and fetal growth restriction. Despite these findings, the knowledge and understanding of the clinical importance and implications of these associations are limited. A systematic review of the association between 25-OHD levels in the first trimester and subsequent adverse pregnancy outcomes concluded that there was no clear definition of vitamin D deficiency in pregnancy. ${ }^{2}$ Although this review identified several studies showing inverse associations between maternal 25-OHD levels in the first trimester and the risk of adverse pregnancy outcomes, the authors did not perform a meta-analysis of the data and quantification of the association, citing inconsistent reporting of results across studies. ${ }^{2}$ 
The literature on vitamin D insufficiency in pregnancy is growing rapidly, with several studies examining a variety of populations and outcomes. This literature requires to be reviewed comprehensively to characterise the associations of vitamin D insufficiency with these disparate outcomes. A recent systematic review found a significant inverse relation between serum 25-OHD levels and the incidence of gestational diabetes. ${ }^{3}$ Since the publication of this review, further studies have been published on this topic, with other clinically important outcomes that have not yet been effectively summarised.

Consequently, translating the current level of knowledge into clinical recommendations has been challenging. A consensus on "target" 25-OHD levels in pregnancy is lacking, and the role of vitamin D supplementation in the prenatal period and during pregnancy and lactation is unclear. Furthermore, there is little evidence on "optimal" supplement dosing. Vitamin D supplementation has the potential to be a simple intervention with significant benefits. Before proceeding with large randomised controlled trials to deal with the efficacy of supplementation, understanding the breadth and quality of observational studies that underpin this evidence is critical.

We reviewed existing evidence on the effect of 25-OHD levels on pregnancy outcomes (pre-eclampsia, gestational diabetes, bacterial vaginosis, and caesarean section) and birth variables (small for gestational age, birth weight, birth length, and head circumference).

\section{Methods}

In accordance with a protocol developed a priori, we identified all relevant articles regardless of language by searching Medline (1966 to August 2012), PubMed (2008 to August 2012), Embase (1980 to August 2012), CINAHL (1981 to August 2012), the Cochrane database of systematic reviews, and the Cochrane database of registered clinical trials. We used search strategies recommended for systematic reviews of observational studies. ${ }^{4}$ We also scanned the bibliographies of identified articles. To allow a systematic review of all studies assessing the association between serum 25-OHD levels and pregnancy outcomes or birth variables our initial search was not limited to observational studies.

We searched the electronic databases using three comprehensive search themes. To identify terms related to the exposure of interest, we did a Boolean search using the term "or" to explode (search by subject heading) and map (search by keyword) the MeSH headings: "vitamin D" OR "calciferol" OR

"ergocalciferol” OR "cholecalciferol” OR "25-OHD”. To identify relevant pregnancy outcomes, we carried out a second Boolean search using the term "or" to explode (search by subject heading) and map (search by keyword) the MeSH headings: "pregnancy" OR "pregnancy complications" OR “pregnancy outcome" OR "caesarean section". Finally, to identify relevant neonatal outcomes, we carried out a third Boolean search using the term "or" to explode (search by subject heading) and map (search by keyword) the MeSH headings: "foetal development" OR "birth weight" OR "small for gestational age". To address pregnancy outcomes we combined the exposures of interest with pregnancy outcomes using the Boolean operator "and" and to address birth variables we combined the exposures of interest with neonatal outcomes using the Boolean operator "and". We then combined the two sets of searches using the Boolean operator "or", limited to human studies. This search excluded other design types using the Boolean operator "not": case reports, comments, editorials, letters, or reviews or systematic or synthesis or quantitative or meta-analysis.

\section{Selection criteria}

Two reviewers (FA, TN) screened abstracts and titles to identify articles for further review. Articles were considered for inclusion if they reported on original data from an original study, included an outcome of interest, and utilised blood samples during pregnancy that assessed serum 25-OHD levels. We excluded articles if they used non-blood measures of 25-OHD (amniotic fluid or placenta), assessed other metabolites of vitamin D (for example, 1,25-dihydroxyvitamin D), reported on biological mechanisms of vitamin D metabolites, or were of non-human studies.

On the initial screen for eligibility of articles the observed agreement between reviewers was $97 \%$, corresponding to substantial agreement $(\kappa=0.79)$. An article was retained if either reviewer believed that it should be retained. To determine which papers were to be included two reviewers $(\mathrm{FA}, \mathrm{TN})$

independently screened the full text of identified articles against inclusion and exclusion criteria. Articles were excluded when serum 25-OHD levels were sampled during or after delivery, the outcomes of interest were not reported, or a control or comparison group was not identified. There was no disagreement between the reviewers on articles for inclusion.

\section{Data extraction}

We developed a data extraction form to collect key indicators of study quality using meta-analysis of observational studies in epidemiology standards. ${ }^{5}$ The key indicators were study design, use of a comparison or control group, definition of 25-OHD cut-off levels, gestational age at serum sampling, quantification method, location or latitude of population, and description of important baseline confounders (ethnicity or race, skin colour, clothing, body mass index, use of vitamin D supplementation, exposure to ultraviolet $\mathrm{B}$, use of sunscreen, and season).

Articles were categorised on the basis of the outcomes of interest: gestational diabetes, pre-eclampsia, bacterial vaginosis, caesarean section, small for gestational age infants, birth weight, birth length, and head circumference. We examined the definitions of gestational diabetes, pre-eclampsia, bacterial vaginosis, and small for gestational age as reported in the articles. Articles reporting on multiple outcomes were included. For studies that measured 25-OHD levels multiple times during pregnancy, we included the earliest measurement in the analysis. Two reviewers (FA, TN) independently extracted information from each article and compared findings; any discrepancies were resolved by consensus. Attempts were made to contact authors of studies with unclear data.

\section{Statistical analysis}

The associations between 25-OHD levels and pregnancy outcomes and birth variables were reported in various ways, including proportions, odds ratios (95\% confidence intervals), means (standard deviations), and medians (interquartile ranges). We converted medians and interquartile ranges to means and standard deviations using previously outlined methods. ${ }^{6}$ Studies varied in their definition of cut-offs for 25-OHD levels (deficiency, insufficiency, and sufficiency). In studies that reported outcomes as proportions in two cut-off categories (deficiency and insufficiency), we combined the numbers to create a category of insufficiency for pregnancy outcomes, defined as a serum concentration less than $75 \mathrm{nmol} / \mathrm{L}$. For birth variables, we defined insufficiency as a serum concentration less than $37.5 \mathrm{nmol} / \mathrm{L}$. To ensure inclusion of all available data, cut-offs were not specified a priori; instead we used the cut-offs 
given within the included studies. If studies reported 25-OHD levels in $\mathrm{ng} / \mathrm{mL}$ we converted the values to $\mathrm{nmol} / \mathrm{L}$.

Given the variability in measurement, we used the adjusted odds ratio and weighted mean difference as the common measures of association across studies. As studies control for potential confounding in different ways and to different degrees, we used the most adjusted reported odds ratio when more than one was reported. In those studies that did not report an adjusted odds ratio, we calculated the odds ratio using proportions. We converted relative risks to odds ratios using the formula: $\mathrm{RR} \times(1-\mathrm{P}) /(1-(\mathrm{P} \times \mathrm{RR}))$ in which $\mathrm{P}$ is the incidence of the outcome of interest in the non-exposed group. ${ }^{7}$ For studies that reported mean levels of 25-OHD, we used the weighted mean difference to compare the levels of 25-OHD between women who did and did not develop the outcome of interest.

We used the "metan" command in Stata to pool the odds ratios and weighted mean differences across studies. Forest plots were used to visually assess pooled estimates and corresponding $95 \%$ confidence intervals. To assess for heterogeneity, we calculated the $\mathrm{Q}$ statistic (significance level of $\mathrm{P}<0.1$ ) and the $\mathrm{I}^{2}$ statistic. To account for potential heterogeneity between studies we used random effect models to obtain pooled effect estimates across studies.

Stratified meta-analyses were done on factors considered to be clinically important, and on those related to study quality or potential heterogeneity. These variables included adjustment for critical confounders, country of origin, 25-OHD cut-off levels, gestational age at sampling, study design, and methods used to quantify 25-OHD. When the number of studies reporting on a specific outcome was small, we did not carry out meta-analysis and stratification. Finally, we carried out metaregression to assess the predictive effect of the variables on heterogeneity. Publication bias was also assessed using Begg's test and visual inspection of funnel plots. All analyses were done with Stata 11.0.

\section{Results}

The literature search identified 3357 articles pertaining to the relevant exposure, outcomes, and study designs of interest (figure $\Downarrow$ ). After the initial screening of abstracts and titles, 51 papers remained for full text review. Hand searching of the bibliographies of these articles identified two additional articles. After full text review, 22 articles were excluded, leaving 31 articles for final inclusion. Ten studies on gestational diabetes, nine on pre-eclampsia, three on bacterial vaginosis, two on caesarean section, and 10 on birth variables were included in the systematic review. One study reported on more than one outcome of interest.

\section{Study characteristics}

Table $1 \Downarrow$ shows the characteristics of the 31 included studies. ${ }^{8-38}$ The studies were published between 1980 and 2012 and the number of participants per study ranged from 95 to 1100 . Studies reporting on gestational diabetes included 687 cases and 3425 controls, whereas studies reporting on pre-eclampsia included 350 cases and 2841 controls.

Women were diagnosed as having gestational diabetes if they had abnormal oral glucose tolerance test results two or three hours after receiving 75 or $100 \mathrm{~g}$ of oral glucose between 24 and 28 weeks of gestation. Pre-eclampsia was defined by new onset hypertension after 20 weeks of gestation (systolic blood pressure $>140 \mathrm{~mm} \mathrm{Hg}$ or diastolic blood pressure $>90 \mathrm{~mm} \mathrm{Hg}$ ) and proteinuria $0.3 \mathrm{~g}$ or more per day or 2 or more + on dipstick testing. Bacterial vaginosis was diagnosed based on a score of 7-10 from a Gram stained vaginal smear, interpreted using Nugent et al's method. ${ }^{39}$ Small for gestational age was defined as a birth weight less than the 10th centile in all of the eligible studies, ${ }^{11} 30333536$ except one (less than fifth centile). ${ }^{38}$

\section{Quality assessment}

Fifteen studies were case-control studies, ${ }^{8} 13-2325303811$ cohort studies, ${ }^{9-112426293133-3537}$ and five other designs. ${ }^{12} 27283236$ All the studies used a comparison group. Some articles reported on confounding factors, such as age, body mass index, use of vitamin D supplementation, gestational age at sampling, season, and race. Several studies used multivariable logistic regression to adjust for these confounding factors, whereas others only assessed the correlation. In addition, studies differed on the number of confounding factors adjusted for, as well as the reporting of effect measures (table $2 \Downarrow$ ).

\section{Association between gestational diabetes and 25-OHD insufficiency}

All 10 studies reporting on gestational diabetes presented their findings as proportions ${ }^{8-17}$ and five also presented their findings as means and medians. ${ }^{912131617}$ Two meta-analyses were conducted. In the first analysis, studies reporting odds ratios (calculated and most adjusted) were pooled to quantify the association between 25-OHD insufficiency and gestational diabetes. The second analysis pooled weighted mean differences to determine if there were significant differences between the mean 25-OHD levels among women who did and did not develop gestational diabetes.

In the first analysis, gestational diabetes was found to be associated with insufficient 25-OHD levels compared with the comparison group, with a pooled odds ratio based on a random effects model of 1.49 (95\% confidence interval 1.18 to 1.88 ). There was no evidence of heterogeneity across studies $(\mathrm{P}=0.58$; $\mathrm{I}^{2}=0.0 \%$ ). (See supplementary file.) To examine the robustness of the risk estimate, several stratified analyses were done based on adjustment for critical confounders, country of origin (developed and developing countries), 25-OHD cut-off concentration $(<50$ and $<75 \mathrm{nmol} / \mathrm{L})$, gestational age at sampling among the studies ( $<16$ weeks and $>16$ weeks), study design (case-control and other design), and 25-OHD quantification methods (high performance liquid chromatography and mass spectrometry assay, or radioimmunoassay) (table $3 \Downarrow$ ). Stratification did not significantly alter the pooled estimate of association in each stratum of interest, with one exception. In the three studies that adjusted for critical confounders the pooled odds ratio increased to 1.98 (95\% confidence interval 1.23 to 3.23). Metaregression analyses did not show adjustment for critical confounders, country of origin, 25-OHD cut-off level, gestational age at sampling, study design, and 25-OHD quantification method to be predictive of heterogeneity. The second analysis showed that pregnant women with gestational diabetes had significantly lower 25-OHD levels than the comparison group (pooled weighted mean difference -7.36 $\mathrm{nmol} / \mathrm{L}, 95 \%$ confidence interval -10.16 to $-4.56 \mathrm{nmol} / \mathrm{L}$ ). Furthermore, the weighted mean difference did not change significantly when stratifed by country of origin and study design.

\section{Association between pre-eclampsia and 25-OHD insufficiency}

Of the nine studies that reported on pre-eclampsia, ${ }^{11}{ }^{18-25}$ seven presented their findings as proportions ${ }^{11}$ 18-20 22-24 $^{\text {and five as }}$ 
means. ${ }^{191-2325}$ The overall meta-analysis using the most adjusted odds ratio showed a significant association between pre-eclampsia and 25-OHD insufficiency compared with the comparison group, with a pooled odds ratio based on a random effects model of 1.79 (95\% confidence interval 1.25 to 2.58 ). (See supplementary file.)

There was no evidence of heterogeneity across studies $(\mathrm{P}=0.81$; $\left.\mathrm{I}^{2}=0.0 \%\right)$. Stratified analyses were done based on adjustment for critical confounders, 25-OHD cut-off concentrations $(<50$ and $<75 \mathrm{nmol} / \mathrm{L}$ ), gestational age at sampling among the studies ( $<16$ weeks and $>16$ weeks), study design (case-control and other design), and 25-OHD quantification methods (high performance liquid chromatography and mass spectrometry assay, or radioimmunoassay). In the stratified analyses, the pooled estimate of the association varied significantly across strata. Adjustment of critical confounders led to a more conservative, and in fact non-significant, pooled estimate of the association between pre-eclampsia and 25-OHD concentration (odds ratio $1.51,95 \%$ confidence interval 0.89 to 2.57 ).

Conversely, when there was no adjustment for confounding, the pooled odds ratio increased to 2.09 (95\% confidence interval 1.26 to 3.46). Similarly, when case-control studies were pooled, the estimate of association increased (2.05, 1.33 to 3.14).

Together these suggest that the pooled estimate of association varies with indicators of study quality. The estimate of association also varied by gestational age at sampling, definition of insufficiency, and method for quantification (table 3). Owing to a small number of studies in each strata, metaregression analyses did not show the following to be predictive of heterogeneity: adjustment for critical confounders, 25-OHD concentration cut-offs, gestational age at sampling, study design, and 25-OHD quantification methods.

When the analysis was conducted on the studies reporting means and standard deviations, ${ }^{192-2325}$ pregnant women with pre-eclampsia had significantly lower concentrations of 25-OHD than the comparison group (pooled weighted mean difference $-14.53 \mathrm{nmol} / \mathrm{L}, 95 \%$ confidence interval -22.57 to -6.49 $\mathrm{nmol} / \mathrm{L})$. All studies reporting on means and standard deviations were of case-control design.

\section{Association between bacterial vaginosis or caesarean section and 25-OHD insufficiency}

Three studies ${ }^{26-28}$ reported an increased risk of bacterial vaginosis in pregnant women with low 25-OHD levels (table 3). One of the studies ${ }^{28}$ reported a significant association between 25-OHD concentrations less than $37.5 \mathrm{nmol} / \mathrm{L}$ and risk of bacterial vaginosis (adjusted odds ratio $4.4 ; \mathrm{P}=0.02$ ). Another of the studies ${ }^{27}$ also found that 25-OHD deficiency was associated with bacterial vaginosis in pregnant women (adjusted odds ratio $2.87,95 \%$ confidence interval 1.13 to 7.28 ). Similarly, the remaining study ${ }^{26}$ found that women with bacterial vaginosis had lower unadjusted 25-OHD levels than women with normal vaginal flora (geometric mean difference -10.6 ; $\mathrm{P}<0.001$ ). A meta-analysis of these three studies could not be conducted owing to differential statistical reporting (adjusted odds ratio and geometric mean).

One group of researchers ${ }^{11}$ found no increased risk of caesarean section in pregnant women with 25-OHD insufficiency, whereas others ${ }^{29}$ showed an increased risk of primary caesarean section among women with $25-\mathrm{OHD}$ concentrations $<37.5 \mathrm{nmol} / \mathrm{L}$ compared with those with concentrations $>80 \mathrm{nmol} / \mathrm{L}$ (table 3 ).

\section{Association between birth variables and 25-OHD insufficiency}

Of the 10 studies that reported on birth variables, ${ }^{11}{ }^{30-38}$ six reported on small for gestational age infants, ${ }^{11} 3033353638$ four on birth weight, ${ }^{31} 343537$ and two on birth length and head circumference. $^{34} 37$

The overall meta-analysis using the most adjusted odds ratio showed a significant association between small for gestational age infants and 25-OHD insufficiency compared with the comparison group (random effects model, pooled odds ratio $1.85,95 \%$ confidence interval 1.52 to 2.26 ). (See supplementary file.) There was no evidence of heterogeneity across studies $\left(\mathrm{P}=0.37 ; \mathrm{I}^{2}=7.8 \%\right)$. A sensitivity analysis excluding a study that was conducted on women who were positive for HIV antibodies $^{36}$ still found a significant effect of 25-OHD insufficiency on small for gestational age infants (table 3 ). Stratified analyses were done based on adjustment for critical confounders, 25-OHD concentration cut-offs $(<37.5$ and $<80$ $\mathrm{nmol} / \mathrm{L})$, gestational age at sampling among the studies $(<16$ and $>16$ weeks), and study design (case-control and other). The association between small for gestational age infants and 25-OHD insufficiency remained significant at all levels of stratification. Stratified analysis based on 25-OHD quantification method was not conducted because only one study ${ }^{38}$ used the high performance liquid chromatography assay method. Metaregression analyses did not show adjustment for critical confounders, 25-OHD level cut-offs, gestational age at sampling, and study design to be predictive of heterogeneity. A small randomised controlled trial of supplementation of vitamin D during pregnancy among Asian women showed almost twice as many small for gestational age infants in the control group $(29 \% v 15 \%))^{32}$ This study was not included in the meta-analysis because participants received additional vitamin $D$ supplementation during pregnancy.

Of the four studies ${ }^{313435}$ that reported on birth weight, infants of mothers with 25-OHD concentrations less than $37.5 \mathrm{nmol} / \mathrm{L}$ during pregnancy had lower birth weight (random weighted mean difference $-130.92 \mathrm{~g}, 95 \%$ confidence interval -186.69 to $-75.14 \mathrm{~g}$ ). However, birth length and head circumference did not differ significantly (table 3 ).

\section{Publication bias}

Visual inspection of Begg's funnel plot of included studies on gestational diabetes, pre-eclampsia, and birth variables revealed asymmetry, raising the possibility of publication bias. The Begg's test was not, however, significant $(\mathrm{P}=0.79$ for gestational diabetes, $\mathrm{P}=0.65$ for pre-eclampsia, $\mathrm{P}=0.57$ for small for gestational age infants, and $\mathrm{P}=0.50$ for birth weight). The observed asymmetry was possible due to the small number of studies included in the meta-analysis.

\section{Discussion}

In this systematic review and meta-analysis we found an association between 25-OHD insufficiency and adverse pregnancy outcomes and birth variables. These findings are of concern, particularly given recent evidence suggesting that 25-OHD deficiency or insufficiency is common during pregnancy, especially among high risk groups, including vegetarians, women with limited sun exposure (for example, those who live in cold climates or in northern latitudes, wear sun screen, or wear protective clothing), and those from ethnic minority groups with darker skin. ${ }^{40-43}$ Vitamin D supplementation may be a simple way to reduce the risk of these adverse outcomes. A recent systematic review showed that evaluation 
of the effect of supplementation during pregnancy on maternal, perinatal, or infant health outcomes is based on limited evidence. ${ }^{44}$ However, despite this limitation the researchers were able to show that daily vitamin D supplementation (800-1000 IU/day) had a protective effect on low birth weight. ${ }^{44}$ These findings, in combination with our results, suggest that low levels of 25-OHD may be a modifiable risk factor in pregnancy, and healthcare providers should at least be encouraging pregnant women to follow current guidelines on recommended daily allowances for vitamin $\mathrm{D}$. While this would seem to be a simple directive, there is active debate on what is considered the appropriate intake of vitamin D in pregnancy, as the recommended intake by bodies that advice on best practices in pregnancy care varies from 600 to $2000 \mathrm{IU} /$ day.

The effect of vitamin D has been described in several organ systems within the human body. ${ }^{45}$ Gene array studies in many cells and tissues show that 1,25-dihydroxycholecalciferol $\left(1,25(\mathrm{OH})_{2} \mathrm{D}\right)$ regulates several genes throughout the body, or as much as $5 \%$ of the human genome. ${ }^{46}{ }^{47}$ How $1,25(\mathrm{OH})_{2} \mathrm{D}$ functions in these tissues and the physiological consequences are not clearly known however. ${ }^{46}{ }^{47}$ Several mechanisms may explain the observed association between 25-OHD level and risk of gestational diabetes. Gestational diabetes is a result of pregnancy induced insulin resistance and impaired compensatory insulin secretion. ${ }^{17}{ }^{48}$ Evidence suggests that vitamin D improves insulin sensitivity by enhancing insulin responsiveness to glucose transport. ${ }^{178}$ In addition, vitamin D may play a role in early placental development through gene regulation and expression, which may affect the development of pre-eclampsia. Although 25-OHD deficiency may affect fetal growth through its effect on fetal bone development, ${ }^{46}$ the biological basis for the association between 25-OHD deficiency and birth weight is unclear. Currently, there is a lack of defined pathways for the relation between biomolecular mechanisms and pregnancy complications and fetal outcomes.

Although it is biologically plausible that low 25-OHD levels could be responsible for the adverse pregnancy and neonatal outcomes examined in this review, owing to the observational nature of the data reviewed we cannot infer causality from these findings. However, when we consider this review and the body of literature with the Bradford Hill ${ }^{49}$ criteria in mind, certain criteria indicate that these associations are possibly not spurious and may be shown to be causal in randomised controlled trials. Our review adds to the biological plausibility argument and shows a consistency in association and an appropriate temporal relation between exposure and outcome. The association between 25-OHD levels and pregnancy related outcomes has been consistently observed in diverse patient populations, and similar results were found after conducting several stratified and sensitivity analyses. We also documented that low 25-OHD levels preceded the outcomes. We cannot be certain, however, that low 25-OHD levels predated pregnancy. Furthermore, 25-OHD levels at different stages of pregnancy may be associated with different clinical outcomes and we were unable to identify such "critical windows" for 25-OHD insufficiency and specific pregnancy outcomes in this review. One study ${ }^{44}$ also suggests that experimental evidence shows that low birth weight might be reduced with vitamin D supplementation.

Our review, summarising existing data, shows an increasingly compelling case for a causal relation between low 25-OHD levels and adverse maternal and neonatal outcomes. However our review also highlights the knowledge gaps in the related literature. We were unable to show a dose-response relation between low 25-OHD levels and outcomes. This may be due to a lack of data at the extremes of the 25-OHD cut-off levels.
This needs to be dealt with in future studies. The quality of individual studies was not always optimal as a result of inconsistent reporting on confounding factors. For example, maternal nutrition was not systematically measured across studies, although it affects birth weight; we stratified our meta-analysis based on whether studies were done in developed and developing countries as a proxy of maternal nutritional status. All studies (with one exception) ${ }^{36}$ were from developed countries and none reported on maternal dietary data. Future endeavours to study this association need to consider, collect, and report consistently on important factors such as nutrition, lifestyle, family history of metabolic complications of pregnancy, maternal weight, sun exposure, skin pigmentation, and exercise so that current knowledge can be refined. This review also suggests that the method used to quantify $25-\mathrm{OHD}$ levels may be an important factor when evaluating the risk of vitamin D deficiency. While both measurements still suggested a risk associated with low 25-OHD levels, a combined high performance liquid chromatography and mass spectrometry assay was associated with more modest estimates of risk that did not reach statistical significance compared with radioimmunoassay methods. This was possibly due to low statistical power, and therefore more work is needed to determine if the risk associated with low 25-OHD levels reported here persists when using a combined high performance liquid chromatography and mass spectrometry assay as the quantification method.

We also acknowledge the limitations of this review and of meta-analytical methods more broadly. Owing to a lack of or limited adjustment for confounding factors in some studies, we used the most adjusted odds ratio in meta-analysis. In some studies an odds ratio was not reported but we were able to calculate an unadjusted odds ratio based on event rates reported in the exposed and unexposed groups. Unadjusted odds ratios must be interpreted with caution as confounding can result in spurious associations. Secondly, many of the studies included were of a case-control design, which could overestimate the effect size of the association and makes the temporal relation between exposure and outcome less clear. Thirdly, the studies varied in their definition of cut-offs for 25-OHD insufficiency; in those that reported separate proportions of deficiency and insufficiency, we combined the numbers to categorise concentrations less than $75 \mathrm{nmol} / \mathrm{L}$ as the insufficiency cut-off for pregnancy outcomes and concentrations less than 37.5 $\mathrm{nmol} / \mathrm{L}$ for birth variables, based on the availability of data. This review did not examine the benefit or risk of having a 25-OHD level above or below a certain cut-off, but shows that within a population of pregnant women, lower levels of 25-OHD increases the risk of adverse outcomes. Further work on what defines a "normal" 25-OHD level in pregnancy is required. Finally, there is a suggestion of publication bias in this meta-analysis, which may in part be explained by the small number of studies available for each outcome of interest.

Limitations aside, this review remains the most comprehensive study of 25-OHD insufficiency in pregnancy to date, including data on over 22000 women. The diversity of location and latitudes, seasonality, ethnicity, body mass index of participants, and dietary vitamin D intake (supplementation and fortification) reported in these studies also allows for increased generalisability of these results to other populations.

Our findings of a significant association between 25-OHD insufficiency and adverse pregnancy outcomes and birth variables are of concern. Although we recognise the methodological limitations of the studies included in this review, our study does serve as a comprehensive review of this literature. 
Despite small trials of vitamin D supplementation in pregnancy showing a reduction in the risk of having small for gestational age infants, there remains a need for large, well designed randomised controlled trials to determine whether strategies to optimise maternal 25-OHD levels are effective in improving pregnancy and neonatal outcomes.

We thank Sue Ross and Rob Weaver for their comments and suggestions on an earlier version of the manuscript and Diane Lorenzetti for her guidance in formulating our literature search strategy. Preliminary results from this manuscript were presented at the Society of Obstetricians and Gynaecologists of Canada Annual Clinical Meeting on 20 June 2012 in Ottawa, Canada (abstract published in Journal of Obstetrics and Gynaecology Canada in May 2012).

Contributors: FA and TN contributed equally to this article and are the guarantors. They had full access to all of the data, acquired the data in the study, and take responsibility for the integrity of the data and the accuracy of the data analysis. FA, TN, PER, and DMR conceived and designed the study, analysed and interpreted the data, and carried out the statistical analysis. All authors drafted the manuscript. FA, TN, DMR, $\mathrm{SCT}$, and MO'B critically revised the manuscript for important intellectual content. PER and DMR supervised the study.

Funding: FA and TN received studentship funding from the University of Calgary Institute for Public Health (Markin Fund for Health and Society); DMR is supported by an AISH (Alberta Innovate Health Solutions) population health investigator award; SCT is supported by an AISH salary support; and MO'B is supported by AISH, the Canadian Institute of Health Research, and the Canadian Foundation for Healthcare Improvement. These agencies did not have any role in the design and conduct of the study; collection, management, analysis, and interpretation of the data; and preparation, review, or approval of the manuscript.

Competing interests: All authors have completed the ICMJE uniform disclosure form at www.icmje.org/coi_disclosure.pdf and declare: no support from any organisation for the submitted work; no financial relationships with any organisations that might have an interest in the submitted work in the previous three years, no other relationships or activities that could appear to have influenced the submitted work. Ethical approval: Not required.

Data sharing: The statistical code and datasets are available from the corresponding author at Doreen.Rabi@albertahealthservices.ca.

$1 \quad$ Kaludjerovic $\mathrm{J}$, Vieth $\mathrm{R}$. Relationship between vitamin $\mathrm{D}$ during perinatal development and health. J Midwifery Womens Health 2010:55:550-60.

2 Nassar N, Halligan GH, Roberts CL, Morris JM, Ashton AW. Systematic review of first-trimester vitamin D normative levels and outcomes of pregnancy. Am J Obstet Gynecol 2011;205:208-7.

3 Poel YH, Hummel P, Lips P, Stam F, van der Ploeg T, Simsek S. Vitamin D and gestational diabetes: a systematic review and meta-analysis. Eur J Intern Med 2012;23:465-9.

4 Egger M, Davey Smith G, Altman D. Systematic reviews in health care: meta-analysis in context. BMJ Publishing Group, 2001

5 Stroup DF, Berlin JA, Morton SC, Olkin I, Williamson GD, Rennie D, et al. Meta-analysis of observational studies in epidemiology: a proposal for reporting. Meta-analysis $\mathrm{O}$ Observational Studies in Epidemiology (MOOSE) group. JAMA 2000;283:2008-12.

6 Hozo SP, Djulbegovic B, Hozo I. Estimating the mean and variance from the median, range, and the size of a sample. BMC Med Res Methodol 2005:5:13.

7 Higgins JT, Green S. Cochrane handbook for systematic reviews of interventions. Wiley-Blackwell, 2008.

8 Baker AM, Haeri S, Camargo CA Jr, Stuebe AM, Boggess KA. First-trimester maternal vitamin $\mathrm{D}$ status and risk for gestational diabetes (GDM) a nested case-control study. Diabetes Metab Res Rev 2012;28:164-8.

9 Clifton-Bligh RJ, McElduff P, McElduff A. Maternal vitamin D deficiency, ethnicity and gestational diabetes. Diabet Med 2008;25:678-84.

10 Farrant HJ, Krishnaveni GV, Hill JC, Boucher BJ, Fisher DJ, Noonan K, et al. Vitamin D insufficiency is common in Indian mothers but is not associated with gestational diabetes or variation in newborn size. Eur J Clin Nutr 2009;63:646-52.

11 Fernandez-Alonso AM, Dionis-Sanchez EC, Chedraui P, Gonzalez-Salmeron MD, Perez-Lopez FR. First-trimester maternal serum 25-hydroxyvitamin $D(3)$ status and pregnancy outcome. Int J Gynaecol Obstet 2011;116:6-9.

12 Maghbooli Z, Hossein-Nezhad A, Karimi F, Shafaei AR, Larijani B. Correlation between vitamin D3 deficiency and insulin resistance in pregnancy. Diabetes Metab Res Rev 2008;24:27-32.

13 Makgoba M, Nelson SM, Savvidou M, Messow CM, Nicolaides K, Sattar N. First-trimester circulating 25-hydroxyvitamin D levels and development of gestational diabetes mellitus. Diabetes Care 2011;34:1091-3.
14 Parlea L, Bromberg IL, Feig DS, Vieth R, Merman E, Lipscombe LL. Association between serum 25-hydroxyvitamin $\mathrm{D}$ in early pregnancy and risk of gestational diabetes mellitus. Diabet Med 2012;29:e25-32.

15 Savvidou MD, Akolekar R, Samaha RB, Masconi AP, Nicolaides KH. Maternal serum 25 -hydroxyvitamin $D$ levels at $11(+0)-13(+6)$ weeks in pregnant women with diabetes mellitus and in those with macrosomic neonates. BJOG 2011;118:951-5.

16 Soheilykhah S, Mojibian M, Rashidi M, Rahimi-Saghand S, Jafari F. Maternal vitamin D status in gestational diabetes mellitus. Nutr Clin Pract 2010;25:524-7.

17 Zhang C, Quu C, Hu FB, David RM, van Dam RM, Bralley A, et al. Maternal plasma 25 -hydroxyvitamin $\mathrm{D}$ concentrations and the risk for gestational diabetes mellitus. PLOS One 2008;3:e3753.

18 Azar M, Basu A, Jenkins AJ, Nankervis AJ, Hanssen KF, Scholz H, et al. Serum carotenoids and fat-soluble vitamins in women with type 1 diabetes and preeclampsia: a longitudinal study. Diabetes Care 2011;34:1258-64.

19 Baker AM, Haeri S, Camargo CA Jr, Espinola JA, Stuebe AM. A nested case-control study of midgestation vitamin D deficiency and risk of severe preeclampsia. J Clin Endocrinol Metab 2010;95:5105-9.

20 Bodnar LM, Catov JM, Simhan HN, Holick MF, Powers RW, Roberts JM. Maternal vitamin D deficiency increases the risk of preeclampsia. J Clin Endocrinol Metab 2007;92:3517-22.

21 Kolusari A, Kurdoglu M, Yildizhan R, Adali E, Edirne T, Cebi A, et al. Catalase activity, serum trace element and heavy metal concentrations, and vitamin $A, D$ and $E$ levels in pre-eclampsia. J Int Med Res 2008;36:1335-41.

22 Powe CE, Seely EW, Rana S, Bhan I, Ecker J, Karumanchi SA, et al. First trimester vitamin $\mathrm{D}$, vitamin $\mathrm{D}$ binding protein, and subsequent preeclampsia. Hypertension 2010;56:758-63.

23 Robinson CJ, Alanis MC, Wagner CL, Hollis BW, Johnson DD. Plasma 25-hydroxyvitamin D levels in early-onset severe preeclampsia. Am J Obstet Gynecol 2010;203:366.e1-6.

24 Wei SQ, Audibert F, Hidiroglou N, Sarafin K, Julien P, Wu Y, et al. Longitudinal vitamin $\mathrm{D}$ status in pregnancy and the risk of pre-eclampsia. BJOG 2012;119:832-9.

25 Yu CK, Ertl R, Skyfta E, Akolekar R, Nicolaides KH. Maternal serum vitamin D levels at 11-13 weeks of gestation in preeclampsia. J Hum Hypertens 2013;27:115-8.

26 Bodnar LM, Krohn MA, Simhan HN. Maternal vitamin D deficiency is associated with bacterial vaginosis in the first trimester of pregnancy. $J$ Nutr 2009;139:1157-61.

27 Hensel KJ, Randis TM, Gelber SE, Ratner AJ. Pregnancy-specific association of vitamin D deficiency and bacterial vaginosis. Am J Obstet Gynecol 2011;204:41-9.

28 McGuire Davis L, Chang S, Mancini J, Nathanson MS, Witter FR, O'Brien KO. Vitamin D insufficiency is prevalent among pregnant African American adolescents. J Pediatr Adolesc Gynceol 2010;23:45-52.

29 Scholl TO, Chen X, Stein P. Maternal vitamin D status and delivery by cesarean. Nutrients 2012;4:319-30.

30 Bodnar LM, Catov JM, Zmuda JM, Cooper ME, Parrott MS, Roberts JM, et al. Maternal serum 25-hydroxyvitamin $D$ concentrations are associated with small-for-gestational age births in white women. $J$ Nutr 2010;140:999-1006.

31 Bowyer L, Catling-Paull C, Diamond T, Homer C, Davis G, Craig ME. Vitamin D, PTH and calcium levels in pregnant women and their neonates. Clin Endocrinol (Oxf) 2009;70:372-7.

32 Brooke OG, Brown IR, Bone CD, Carter ND, Cleeve HJ, Maxwell JD, et al. Vitamin D supplements in pregnant Asian women: effects on calcium status and fetal growth. $B M J$ 1980;280:751-4.

33 Burris HH, Rifas-Shiman SL, Camargo CA Jr, Litonjua AA, Huh SY, Rich-Edwards JW, et al. Plasma 25-hydroxyvitamin $D$ during pregnancy and small-for-gestational age in black and white infants. Ann Epidemiol 2012;22:581-6.

34 Gale CR, Robinson SM, Harvey NC, Javaid MK, Jiang B, Martyn CN, et al. Maternal vitamin D status during pregnancy and child outcomes. Eur J Clin Nutr 2008;62:68-77.

35 Leffelaar ER, Vrijkotte TG, van EM. Maternal early pregnancy vitamin D status in relation to fetal and neonatal growth: results of the multi-ethnic Amsterdam Born Children and their Development cohort. Br J Nutr 2010;104:108-17.

36 Mehta S, Hunter DJ, Mugusi FM, Spiegelman D, Manji KP, Giovannucci EL, et al. Perinatal outcomes, including mother-to-child transmission of HIV, and child mortality and their association with maternal vitamin D status in Tanzania. J Infect Dis 2009;200:1022-30.

37 Morley R, Carlin JB, Pasco JA, Wark JD. Maternal 25-hydroxyvitamin D and parathyroid hormone concentrations and offspring birth size. J Clin Endocrinol Metab 2006;91:906-12.

38 Ertl R, Yu CK, Samaha R, Akolekar R, Nicolaides KH. Maternal serum vitamin D at 11-13 weeks in pregnancies delivering small for gestational age neonates. Fetal Diagn Ther 2012;31:103-8.

39 Nugent RP, Krohn MA, Hillier SL. Reliability of diagnosing bacterial vaginosis is improved by a standardized method of gram stain interpretation. J Clin Microbiol 1991;29:297-301.

40 Hollis $\mathrm{BW}$, Wagner $\mathrm{CL}$. Assessment of dietary vitamin $\mathrm{D}$ requirements during pregnancy and lactation. Am J Clin Nutr 2004:79:717-26.

41 Lee JM, Smith JR, Philipp BL, Chen TC, Mathieu J, Holick MF. Vitamin D deficiency in a healthy group of mothers and newborn infants. Clin Pediatr (Phila) 2007;46:42-4.

42 Bodnar LM, Simhan HN, Powers RW, Frank MP, Cooperstein E, Roberts JM. High prevalence of vitamin $D$ insufficiency in black and white pregnant women residing in the northern United States and their neonates. J Nutr 2007;137:447-52.

43 Dijkstra SH, van Beek A, Janssen JW, de Vleeschouwer LH, Huysman WA, van den Akker EL. High prevalence of vitamin D deficiency in newborn infants of high-risk mothers. Arch Dis Child 2007;92:750-3.

44 Thorne-Lyman A, Fawzi WW. Vitamin D during pregnancy and maternal, neonatal and infant health outcomes: a systematic review and meta-analysis. Paediatr Perinat Epidemio 2012;26(suppl 1):75-90.

45 Holick MF. Vitamin D deficiency. N Engl J Med 2007:357:266-81.

46 Zella LA, Shevde NK, Hollis BW, Cooke NE, Pike JW. Vitamin D-binding protein influences total circulating levels of 1,25 -dihydroxyvitamin D3 but does not directly modulate the bioactive levels of the hormone in vivo. Endocrinology 2008;149:3656-67.

47 Jones G, Strugnell SA, DeLuca HF. Current understanding of the molecular actions of vitamin D. Physiol Rev 1998;78:1193-231.

48 Buchanan TA, Xiang AH. Gestational diabetes mellitus. J Clin Invest 2005;115:485-91.

49 Hill AB. The environment and disase: association or causation? Proc $R$ Soc Med 1965;58:295-300.

Accepted: 5 February 2013 


\section{What is already known on this topic}

Evidence is emerging that lower levels of 25-hydroxyvitamin D (25-OHD) are associated with adverse health outcomes, including pregnancy outcomes

\section{What this study adds}

Vitamin D insufficiency is associated with an increased risk of gestational diabetes, pre-eclampsia, and small for gestational age infants Pregnant women with low 25-OHD levels had an increased risk of bacterial vaginosis and lower birth weight infants, but not delivery by caesarean section

This is an open-access article distributed under the terms of the Creative Commons Attribution Non-commercial License, which permits use, distribution, and reproduction in any medium, provided the original work is properly cited, the use is non commercial and is otherwise in compliance with the license. See: http://creativecommons.org/licenses/bync/2.0/ and http://creativecommons.org/licenses/by-nc/2.0/legalcode. 


\section{Tables}

\begin{tabular}{|c|c|c|c|c|c|c|c|}
\hline \multicolumn{8}{|c|}{ Table 1/ Characteristics of included studies } \\
\hline Trials by outcome & Location/latitude & Participants & Ethnicity & $\begin{array}{c}\text { Gestational } \\
\text { age at time } \\
\text { of sampling } \\
\text { (weeks) }\end{array}$ & $\begin{array}{c}25-\mathrm{OHD} \\
\text { concentration } \\
\text { cut-off (nmol/L) }\end{array}$ & $\begin{array}{l}\text { 25-OHD } \\
\text { quantification } \\
\text { method } \neq\end{array}$ & Study design \\
\hline \multicolumn{8}{|l|}{$\begin{array}{l}\text { Gestational } \\
\text { diabetes: }\end{array}$} \\
\hline Baker et al, $2012^{8}$ & USA $/ 35^{\circ} \mathrm{N}$ & $\begin{array}{l}\text { Gestational diabetes: } 60, \text { control: } \\
120\end{array}$ & $\begin{array}{l}52 \% \text { white, } 33 \% \\
\text { black, } 10 \% \\
\text { Hispanic, } 5 \% \\
\text { other }\end{array}$ & $12-13$ & $\begin{array}{c}<50 \text { (reference } \\
>75)\end{array}$ & HPLC and MS & $\begin{array}{l}\text { Nested } \\
\text { case-control }\end{array}$ \\
\hline $\begin{array}{l}\text { Clifton-Bligh et al, } \\
2008^{9}\end{array}$ & Australia $/ 33^{\circ} \mathrm{S}$ & $\begin{array}{l}\text { Gestational diabetes: } 81 \text {, control: } \\
226\end{array}$ & $\begin{array}{l}\text { 54.7\% European, } \\
28 \% \text { South East } \\
\text { Asian, } 6.8 \% \\
\text { Asian, } 6.2 \% \\
\text { Middle Eastern }\end{array}$ & 28.7 & $\begin{array}{c}<50 \text { (reference } \\
>50)\end{array}$ & HPLC and MS & $\begin{array}{l}\text { Prospective } \\
\text { cohort }\end{array}$ \\
\hline $\begin{array}{l}\text { Farrant et al, } \\
2009^{10}\end{array}$ & India/ $12^{\circ} \mathrm{N}$ & $\begin{array}{l}\text { Gestational diabetes: } 39 \text {, control: } \\
520\end{array}$ & Indian & 30 & $\begin{array}{c}<50 \text { (reference } \\
>50\end{array}$ & RIA & $\begin{array}{l}\text { Prospective } \\
\text { cohort }\end{array}$ \\
\hline $\begin{array}{l}\text { Fernandez-Alonso } \\
\text { et al, 201111 }\end{array}$ & Spain $/ 36^{\circ} \mathrm{N}$ & $\begin{array}{l}\text { Gestational diabetes: } 36 \text {, control: } \\
430\end{array}$ & Spanish & $11-14,36-39$ & $\begin{array}{c}<75 \text { (reference } \\
>75 \text { ) }\end{array}$ & ECL & $\begin{array}{l}\text { Prospective } \\
\text { cohort }\end{array}$ \\
\hline $\begin{array}{l}\text { Maghbooli et al, } \\
2008^{12}\end{array}$ & $\operatorname{Iran} / 32^{\circ} \mathrm{N}$ & $\begin{array}{l}\text { Gestational diabetes: } 52 \text {, control: } \\
527\end{array}$ & Iranian & 24 & $\begin{array}{c}>35 \text { (reference } \\
>35 \text { ) }\end{array}$ & RIA & Cross sectional \\
\hline $\begin{array}{l}\text { Makgoba et al, } \\
2011^{13}\end{array}$ & $\mathrm{UK} / 51^{\circ} \mathrm{N}$ & $\begin{array}{l}\text { Gestational diabetes: } 90, \text { control: } \\
158\end{array}$ & $\begin{array}{l}68.4 \% \text { white, } \\
19.6 \% \text { African, } \\
7.6 \% \text { Asian }\end{array}$ & 28 & $\begin{array}{c}<50 \text { (reference } \\
>50 \text { ) }\end{array}$ & HPLC and MS & Case-control \\
\hline Parlea et al, $2012^{14}$ & Canada $/ 43^{\circ} \mathrm{N}$ & $\begin{array}{l}\text { Gestational diabetes: } 118 \text {, control: } \\
219\end{array}$ & $\begin{array}{l}60 \% \text { white, } 34 \% \\
\text { Asian, } 5 \% \text { Black, } \\
1 \% \text { other }\end{array}$ & $15-18$ & $\begin{array}{c}<73.5 \text { (reference } \\
>73.5 \text { ) }\end{array}$ & ECL & $\begin{array}{l}\text { Nested } \\
\text { case-control }\end{array}$ \\
\hline $\begin{array}{l}\text { Savvidou et al, } \\
2011^{15}\end{array}$ & $\mathrm{UK} / 51^{\circ} \mathrm{N}$ & $\begin{array}{l}\text { Gestational diabetes: } 100 \text {, control: } \\
1000\end{array}$ & $\begin{array}{l}58 \% \text { white, } 33 \% \\
\text { African, } 9.5 \% \\
\text { Asian }\end{array}$ & 12.4 & $\begin{array}{c}<75 \text { (reference } \\
>75 \text { ) }\end{array}$ & HPLC and MS & Case-control \\
\hline $\begin{array}{l}\text { Soheilykhah et al, } \\
2010^{16}\end{array}$ & $\operatorname{Iran} / 32^{\circ} \mathrm{N}$ & $\begin{array}{l}\text { Gestational diabetes: } 54, \text { control: } \\
111\end{array}$ & Iranian & 22.03 & $\begin{array}{c}<50 \text { (reference } \\
\quad>75 \text { ) }\end{array}$ & ELISA & Case-control \\
\hline Zhang et al, $2008^{17}$ & USA $/ 47^{\circ} \mathrm{N}$ & $\begin{array}{l}\text { Gestational diabetes: } 57 \text {, control: } \\
114\end{array}$ & $\begin{array}{l}70.2 \% \text { white, } \\
3.5 \% \text { African, } \\
26.3 \% \text { other }\end{array}$ & 16 & $\begin{array}{c}<50 \text { (reference } \\
>75)\end{array}$ & EIA & $\begin{array}{l}\text { Nested } \\
\text { case-control }\end{array}$ \\
\hline \multicolumn{8}{|l|}{ Pre-eclampsia: } \\
\hline Azar et al, $2011^{18}$ & $\begin{array}{l}\text { Norway } / 62^{\circ} \mathrm{N}, \\
\text { USA } 47^{\circ} \mathrm{N}, \\
\text { Australia/ } / 33^{\circ} \mathrm{N}\end{array}$ & $\begin{array}{l}\text { Gestational diabetes, } \\
\text { pre-eclampsia: } 23 \text {, no gestational } \\
\text { diabetes, no pre-eclampsia: } 20\end{array}$ & White & $\begin{array}{c}12,21,32 \\
37\end{array}$ & $\begin{array}{l}<75 \text { (reference } \\
>75 \text { ) }\end{array}$ & HPLC and MS & Case-control \\
\hline Baker et al, $2010^{19}$ & USA $/ 35^{\circ} \mathrm{N}$ & $\begin{array}{l}\text { Pre-eclampsia: } 43 \text { severe, severe } \\
\text { pre-eclampsia: } 43, \text { control: } 198\end{array}$ & $\begin{array}{l}29 \% \text { white, } 40 \% \\
\text { African, } 26 \% \\
\text { Hispanic, } 5 \% \\
\text { other }\end{array}$ & 17 & $\begin{array}{l}<75 \text { (reference } \\
>75 \text { ) }\end{array}$ & HPLC and MS & $\begin{array}{l}\text { Nested } \\
\text { case-control }\end{array}$ \\
\hline $\begin{array}{l}\text { Bodnar et al, } \\
2007^{20}\end{array}$ & USA $/ 40^{\circ} \mathrm{N}$ & Pre-eclampsia: 49, control: 216 & $\begin{array}{l}68.5 \% \text { white } \\
31.5 \% \text { African }\end{array}$ & 10.4 & $\begin{array}{c}<75 \text { (reference } \\
>75 \text { ) }\end{array}$ & ELISA & $\begin{array}{l}\text { Nested } \\
\text { case-control }\end{array}$ \\
\hline $\begin{array}{l}\text { Fernandez-Alonso } \\
\text { et al, 201111 }\end{array}$ & Spain $/ 36^{\circ} \mathrm{N}$ & Pre-eclampsia: 7, control: 459 & Spanish & $11-14,36-39$ & $\begin{array}{c}<75 \text { (reference } \\
>75 \text { ) }\end{array}$ & ECL & $\begin{array}{l}\text { Prospective } \\
\text { cohort }\end{array}$ \\
\hline $\begin{array}{l}\text { Kolusari et al, } \\
2008^{21}\end{array}$ & Turkey $/ 39^{\circ} \mathrm{N}$ & Pre-eclampsia: 47 , control: 48 & Turkish & 34 & None & HPLC & Case-control \\
\hline Powe et al, $2010^{22}$ & USA $/ 42^{\circ} \mathrm{N}$ & Pre-eclampsia: 39, control: 131 & $53.8 \%$ white & 11.6 & $\begin{array}{c}<37 \text { (reference } \\
>37 \text { ) }\end{array}$ & HPLC and MS & $\begin{array}{l}\text { Nested } \\
\text { case-control }\end{array}$ \\
\hline $\begin{array}{l}\text { Robinson et al, } \\
2010^{23}\end{array}$ & USA $/ 32^{\circ} \mathrm{N}$ & $\begin{array}{l}\text { Pre-eclampsia: } 50, \\
\text { control: } 100\end{array}$ & $48 \%$ African & 29 & $\begin{array}{c}>80 \text { (reference } \\
>80)\end{array}$ & RIA & Case-control \\
\hline Wei et al, $2012^{24}$ & Canada $/ 49^{\circ} \mathrm{N}$ & $\begin{array}{l}\text { Pre-eclampsia: } 32 \text {, } \\
\text { control: } 665\end{array}$ & $89 \%$ white & $12-18^{*}$ & $\begin{array}{c}<50 \text { (reference } \\
>50 \text { ) }\end{array}$ & ECL & $\begin{array}{l}\text { Prospective } \\
\text { cohort }\end{array}$ \\
\hline Yu et al, $2012^{25}$ & $\mathrm{UK} / 51^{\circ} \mathrm{N}$ & $\begin{array}{l}\text { Pre-eclampsia: } 60 \\
\text { control: } 1000\end{array}$ & $\begin{array}{l}50 \% \text { white, } 38 \% \\
\text { African, } 12 \% \\
\text { Asian }\end{array}$ & $11-13$ & None & HPLC and MS & Case-control \\
\hline
\end{tabular}


Table 1 (continued)

\begin{tabular}{|c|c|c|c|c|c|c|c|}
\hline Trials by outcome & Location/latitude & Participants & Ethnicity & $\begin{array}{l}\text { Gestational } \\
\text { age at time } \\
\text { of sampling } \\
\text { (weeks) }\end{array}$ & $\begin{array}{c}\text { 25-OHD } \\
\text { concentration } \\
\text { cut-off (nmol/L) }\end{array}$ & $\begin{array}{c}\text { 25-OHD } \\
\text { quantification } \\
\text { method } \ddagger\end{array}$ & Study design \\
\hline \multicolumn{8}{|l|}{ Bacterial vaginosis: } \\
\hline $\begin{array}{l}\text { Bodnar et al, } \\
2009^{26}\end{array}$ & USA $/ 40^{\circ} \mathrm{N}$ & $\begin{array}{l}\text { Cases: } 192 \text { with } \\
\text { bacterial vaginosis, } \\
\text { control: } 277 \text { without } \\
\text { bacterial vaginosis }\end{array}$ & $\begin{array}{l}\text { 44.6\% white, } \\
55.4 \% \text { African }\end{array}$ & 9.5 & $\begin{array}{c}<20,20-<37.5 \\
37.5-<50,50-<80 \\
>80\end{array}$ & $\mathrm{RIA}$ & $\begin{array}{l}\text { Prospective } \\
\text { cohort }\end{array}$ \\
\hline $\begin{array}{l}\text { Hensel et al, } \\
2011^{27}\end{array}$ & Across USA & $\begin{array}{l}\text { Pregnant: } 440.29 \% \\
\text { of group with } \\
\text { bacterial vaginosis. } \\
\text { Non-pregnant: } 3523\end{array}$ & $\begin{array}{l}\text { White, African, } \\
\text { Mexican }\end{array}$ & $\begin{array}{c}\text { During } \\
\text { pregnancy }\end{array}$ & $<75$ & $\begin{array}{l}\text { Variable, } \\
\text { different } \\
\text { laboratories }\end{array}$ & Cross sectional \\
\hline $\begin{array}{l}\text { McGuire Davis et } \\
\text { al, } 2010^{28}\end{array}$ & USA $/ 39^{\circ} \mathrm{N}$ & $\begin{array}{l}80 \text { adolescents }(\leq 18 \\
\text { years) }\end{array}$ & African & 18 to 29 & $\begin{array}{c}<37.5 \text { (reference } \\
>50 \text { ) }\end{array}$ & RIA & Cross sectional \\
\hline $\begin{array}{l}\text { Fernandez-Alonso } \\
\text { et al, } 2011^{11}\end{array}$ & Spain $/ 36^{\circ} \mathrm{N}$ & $\begin{array}{l}\text { Caesarean section: } \\
105, \text { control: } 361\end{array}$ & Spanish & $11-14,36-39$ & $\begin{array}{c}<75 \text { (reference } \\
>75)\end{array}$ & $\mathrm{ECL}$ & $\begin{array}{l}\text { Prospective } \\
\text { cohort }\end{array}$ \\
\hline Scholl et al, $2012^{29}$ & USA $/ 35^{\circ} \mathrm{N}$ & $\begin{array}{l}\text { Cases: } 290, \\
\text { controls: } 863\end{array}$ & $\begin{array}{l}35 \% \text { black, } 51 \% \\
\text { Hispanic, } 14 \% \\
\text { white }\end{array}$ & 14 & $\begin{array}{c}<37.5 \text { (reference } \\
37.5-80 \text { ) }\end{array}$ & HPLC & Cohort \\
\hline $\begin{array}{l}\text { Bodnar et al, } \\
2010^{30}\end{array}$ & USA $/ 40^{\circ} \mathrm{N}$ & $\begin{array}{l}\text { Small for gestational } \\
\text { age: } 111 \text {, controls: } \\
301\end{array}$ & $\begin{array}{l}273 \text { white, } 139 \\
\text { black }\end{array}$ & $<22$ & $\begin{array}{c}<37.5 \text { (reference } \\
37.5-75)\end{array}$ & ELISA & $\begin{array}{l}\text { Nested } \\
\text { case-control }\end{array}$ \\
\hline $\begin{array}{l}\text { Bowyer et al, } \\
2009^{31}\end{array}$ & Australia $/ 33^{\circ} \mathrm{S}$ & 971 & $\begin{array}{l}59 \% \text { dark } \\
\text { maternal skin }\end{array}$ & 23-32 & $\begin{array}{c}<25 \text { (reference } \\
26-50)\end{array}$ & $\mathrm{ECL}$ & $\begin{array}{l}\text { Prospective } \\
\text { cohort }\end{array}$ \\
\hline $\begin{array}{l}\text { Brooke et al, } \\
1980^{32}\end{array}$ & $\mathrm{UK} / 51^{\circ} \mathrm{N}$ & $\begin{array}{l}\text { Treatment (calciferol } \\
1000 \text { IU/day): } 59, \\
\text { control: } 67\end{array}$ & Asian immigrants & $28-32$ & NA & HPLC & $\begin{array}{l}\text { Double blinded } \\
\text { randomised } \\
\text { controlled trial }\end{array}$ \\
\hline Burris et al, $2012^{33}$ & USA $/ 42^{\circ} \mathrm{N}$ & $\begin{array}{l}\text { Small for gestational } \\
\text { age: } 7 \dagger \text {, control: } 22\end{array}$ & $\begin{array}{l}72.3 \% \text { black, } \\
27.6 \% \text { white }\end{array}$ & $26-28$ & $\begin{array}{c}<25 \\
\text { (reference50-75) }\end{array}$ & ECL and RIA & $\begin{array}{l}\text { Prospective } \\
\text { cohort }\end{array}$ \\
\hline Ertl et al, $2012^{38}$ & UK $/ 51^{\circ} \mathrm{N}$ & $\begin{array}{l}\text { Small for gestational } \\
\text { age: } 150 \text {, control: } \\
1000\end{array}$ & $\begin{array}{l}50 \% \text { white, } 50 \% \\
\text { African }\end{array}$ & $11-13$ & $\begin{array}{c}<50 \text { (reference } \\
50-75)\end{array}$ & HPLC and MS & Case-control \\
\hline $\begin{array}{l}\text { Fernandez-Alonso } \\
\text { et al, } 2011^{11}\end{array}$ & Spain $/ 36^{\circ} \mathrm{N}$ & $\begin{array}{l}\text { Small for gestational } \\
\text { age: } 46 \text {, control: } 406\end{array}$ & Spanish & $11-14,36-39$ & $\begin{array}{c}<50 \text { (reference } \\
>75)\end{array}$ & ECL & $\begin{array}{l}\text { Prospective } \\
\text { cohort }\end{array}$ \\
\hline Gale et al, $2008^{34}$ & UK $/ 51^{\circ} \mathrm{N}$ & 466 & white & 32 & $\begin{array}{c}<30 \text { (reference } \\
>75)\end{array}$ & RIA & $\begin{array}{l}\text { Retrospective } \\
\text { cohort }\end{array}$ \\
\hline $\begin{array}{l}\text { Leffelaar et al, } \\
2010^{35}\end{array}$ & Netherlands $/ 51^{\circ} \mathrm{N}$ & $\begin{array}{l}\text { Vitamin D deficient } \\
861 \text {, insufficient } 797 \text {, } \\
\text { adequate } 2072\end{array}$ & $\begin{array}{l}68.9 \% \text { white, } \\
31.2 \% \text { non-white }\end{array}$ & $<18$ & $\begin{array}{c}<29.9 \text { (reference } \\
>50 \text { ) }\end{array}$ & EIA & $\begin{array}{l}\text { Prospective } \\
\text { cohort }\end{array}$ \\
\hline Mehta et al, $2009^{36}$ & Tanzania $/ 6^{\circ} \mathrm{S}$ & $\begin{array}{l}1078 \text { pregnant } \\
\text { women infected with } \\
\text { HIV }\end{array}$ & African & $12-27$ & $\begin{array}{c}<80 \text { (reference } \\
>80)\end{array}$ & $\mathrm{ECL}$ & $\begin{array}{l}\text { Secondary } \\
\text { analysis of } \\
\text { randomised } \\
\text { controlled trial }\end{array}$ \\
\hline Morley et al, $2006^{37}$ & Australia $/ 38^{\circ} \mathrm{S}$ & 374 & $\begin{array}{l}93 \% \text { Australian } \\
\text { born }\end{array}$ & $28-32$ & $\begin{array}{c}<28 \text { (reference } \\
>28)\end{array}$ & RIA & $\begin{array}{l}\text { Prospective } \\
\text { cohort }\end{array}$ \\
\hline
\end{tabular}

25-OHD=25-hydroxyvitamin D; ELISA=enzyme linked immunosorbent assay; RIA=radioimmunoassay; HPLC=high performance liquid chromatography; MS=mass

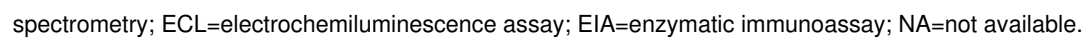

*Serum concentration data from 12-18 weeks of pregnancy were utilised.

†Serum concentration data from $<25 \mathrm{nmol} / \mathrm{L}$ were utilised. 


\begin{tabular}{|c|c|c|c|}
\hline Source & Reported measures & Method of adjustment & Confounding factors \\
\hline \multicolumn{4}{|l|}{ Gestational diabetes: } \\
\hline Baker et al, $2012^{8}$ & Adjusted odds ratio & Logistic regression model & $\begin{array}{l}\text { Age, insurance status, body mass index, gestational } \\
\text { age at serum collection, season }\end{array}$ \\
\hline Clifton-Bligh et al, $2008^{9}$ & Mean (SD) odds ratio & No adjustment & None \\
\hline Farrant et al, $2009^{10}$ & $\begin{array}{l}\text { Geometric mean (interquartile range), } \\
\text { proportions }\end{array}$ & $\begin{array}{l}\text { Multiple linear and logistic regression } \\
\text { model }\end{array}$ & Age, fat mass or body mass index, diabetes status \\
\hline Fernández-Alonso et al, $2011^{11}$ & Proportions & None & None \\
\hline Maghbooli et al, $2008^{12}$ & Mean (SD) proportions & $\begin{array}{l}\text { Assessment of correlation or no } \\
\text { adjustment }\end{array}$ & None \\
\hline Makgoba et al, $2011^{13}$ & Mean (SD) proportions & $\begin{array}{l}\text { Assessment of correlation/no } \\
\text { adjustment }\end{array}$ & None \\
\hline Parlea et al, $2012^{14}$ & Adjusted odds ratio & Logistic regression model & Age and weight \\
\hline Savvidou et al, $2011^{15}$ & $\begin{array}{l}\text { Median (interquartile range), } \\
\text { proportions }\end{array}$ & Multiple logistic regression model & $\begin{array}{l}\text { Age, body mass index, smoking status, method of } \\
\text { conception, season, race }\end{array}$ \\
\hline Soheilykhah et al, $2010^{16}$ & $\begin{array}{l}\text { Proportions, median (interquartile } \\
\text { range) }\end{array}$ & $\begin{array}{l}\text { Assessment of correlation/no } \\
\text { adjustment }\end{array}$ & None \\
\hline Zhang et al, $2008^{17}$ & Adjusted odds ratio, mean (SD) & Logistic regression model & $\begin{array}{l}\text { Age, prepregnancy body mass index, family history } \\
\text { of type } 2 \text { diabetes, race }\end{array}$ \\
\hline \multicolumn{4}{|l|}{ Pre-eclampsia: } \\
\hline Azar et al, $2011^{18}$ & Proportions & Adjusted method not specified & Body mass index \\
\hline Baker et al, $2010^{19}$ & Adjusted odds ratio & Multiple logistic regression model & $\begin{array}{l}\text { Age, body mass index, gestational age at serum } \\
\text { sampling, season, parity }\end{array}$ \\
\hline Bodnar et al, $2007^{20}$ & $\begin{array}{l}\text { Adjusted odds ratio, adjusted } \\
\text { geometric mean }(95 \% \mathrm{Cl}) \\
\text { proportions }\end{array}$ & Multiple regression models & $\begin{array}{l}\text { Prepregnancy body mass index, gestational age at } \\
\text { serum sampling, education, season, race }\end{array}$ \\
\hline Fernández-Alonso et al, $2011^{11}$ & Proportions & None & None \\
\hline Kolusari et al, $2008^{21}$ & Mean (SD) & None & NA \\
\hline Powe et al, $2010^{22}$ & Adjusted odds ratio, mean (SD) & Multiple logistic regression model & Body mass index, season, race \\
\hline Robinson et al, $2010^{23}$ & $\begin{array}{l}\text { Adjusted odds ratio for continuous } \\
\text { level, median (interquartile range), } \\
\text { proportions }\end{array}$ & Multiple linear regression model & $\begin{array}{l}\text { Age, prepregnancy body mass index, gestational } \\
\text { age at serum sampling, race }\end{array}$ \\
\hline Wei et al, $2012^{24}$ & Adjusted odds ratio & Multiple logistic regression model & Age, smoking status, body mass index, season \\
\hline Yu et al, $2012^{25}$ & Median (interquartile range) & None & NA \\
\hline \multicolumn{4}{|l|}{ Bacterial vaginosis: } \\
\hline Bodnar et al, $2009^{26}$ & Prevalence ratio & $\begin{array}{l}\text { Multivariable Poisson regression } \\
\text { model }\end{array}$ & Presence of sexually transmitted disease, race \\
\hline Hensel et al, $2011^{27}$ & Adjusted odds ratio & Multiple logistic regression model & $\begin{array}{l}\text { Age, body mass index, education, race, poverty } \\
\text { index, marital status, number of lifetime partners, } \\
\text { unprotected sex, current contraceptives use }\end{array}$ \\
\hline McGuire Davis et al, $2010^{28}$ & Odds ratio & Multiple logistic regression model & Season \\
\hline Fernández-Alonso et al, $2011^{11}$ & Proportions & None & None \\
\hline Scholl et al, $2012^{29}$ & Adjusted odds ratio & Multiple logistic regression model & $\begin{array}{l}\text { Age, parity, ethnicity, smoking status, gestational } \\
\text { age at serum sampling, season, body mass index }\end{array}$ \\
\hline \multicolumn{4}{|l|}{ Birth variables } \\
\hline Bodnar et al, $2010^{30}$ & Adjusted odds ratio & Multiple logistic regression model & $\begin{array}{l}\text { Age, gestational age at serum sampling, marital } \\
\text { status, season, body mass index, smoking during } \\
\text { pregnancy, socioeconomic status, periconceptional } \\
\text { multivitamin use, preconceptional physical activity }\end{array}$ \\
\hline Bowyer et al, $2009^{31}$ & Adjusted mean difference & Linear regression model & $\begin{array}{l}\text { Gestational age at serum sampling, age, maternal } \\
\text { birth place }\end{array}$ \\
\hline Brooke et al, $1980^{32}$ & Mean (SE) & None & None \\
\hline Burris et al, $2012^{33}$ & Adjusted odds ratio & Logistic regression model & Season, age, prepregnancy body mass index, race \\
\hline Ertl et al, $2012^{38}$ & Proportions & None & None \\
\hline Fernández-Alonso et al, $2011^{11}$ & Proportions & None & None \\
\hline Gale et al, $2008^{34}$ & Mean (SD) & None & None \\
\hline
\end{tabular}


Table 2 (continued)

\begin{tabular}{llll}
$\begin{array}{l}\text { Source } \\
\text { Leffelaar et al, } 2010^{35}\end{array}$ & \multicolumn{1}{c}{ Reported measures } & \multicolumn{1}{c}{$\begin{array}{c}\text { Method of adjustment } \\
\text { Odds ratio }\end{array}$} & $\begin{array}{c}\text { Multiple logistic regression model } \\
\text { Infant sex, maternal height, parity, age, smoking, } \\
\text { prepregnancy body mass index, educational level, } \\
\text { ethnicity, vitamin D status }\end{array}$ \\
\hline Mehta et al, $2009^{36}$ & Relative risk & Multivariable analysis & $\begin{array}{l}\text { Multivitamin supplementation, maternal age, CD4 } \\
\text { cell count, and HIV disease stage at baseline }\end{array}$ \\
\hline Morley et al, $2006^{37}$ & Adjusted mean difference & Linear regression model & Infant sex, maternal height, first child, smoking, \\
& & & season \\
\hline
\end{tabular}

$\mathrm{NA}=$ not available. 
Table 3| Results of insufficient 25-hydroxyvitamin D (25-OHD) levels and pregnancy and neonatal outcomes

\begin{tabular}{|c|c|c|c|}
\hline Outcomes & No of studies & Pooled odds ratio (95\% Cl) & Pooled weighted mean difference $(95 \% \mathrm{Cl})(\mathrm{nmol} / \mathrm{L})$ \\
\hline \multicolumn{4}{|l|}{ Gestational diabetes } \\
\hline Overall & 10 & 1.49 (1.18 to 1.89$)$ & - \\
\hline \multicolumn{4}{|l|}{ Stratified analysis*: } \\
\hline Adjusted for critical confounders & 3 & 1.98 (1.23 to 3.23$)$ & - \\
\hline Unadjusted for critical confounders & 7 & 1.37 (1.05 to 1.78$)$ & - \\
\hline Developed countries & 7 & 1.50 (1.16 to 1.95$)$ & - \\
\hline Developing countries & 3 & 1.45 (0.89 to 2.37 ) & - \\
\hline $25-\mathrm{OHD}<50 \mathrm{nmol} / \mathrm{L}$ & 7 & $1.47(1.09$ to 1.99$)$ & - \\
\hline $25-\mathrm{OHD}<75 \mathrm{nmol} / \mathrm{L}$ & 3 & 1.52 (1.06 to 2.18$)$ & - \\
\hline Gestational age of sampling $<16$ weeks & 5 & 1.55 (1.12 to 2.15$)$ & - \\
\hline Gestational age of sampling $>16$ weeks & 5 & 1.44 (1.04 to 1.99$)$ & - \\
\hline Case-control study design & 6 & 1.57 (1.19 to 2.09$)$ & - \\
\hline Other study design & 4 & 1.34 (0.90 to 1.99$)$ & - \\
\hline HPLC-MS assay & 4 & 1.34 (0.96 to 1.87$)$ & - \\
\hline Radioimmunoassay & 6 & 1.65 (1.19 to 2.27$)$ & - \\
\hline Overall & 5 & - & $-7.36(-10.16$ to -4.56$)$ \\
\hline Sensitivity analysis $\dagger$ & 4 & - & $-6.75(-9.23$ to -4.26$)$ \\
\hline Stratified analysis: & & - & \\
\hline Developed countries & 3 & - & $-7.12(-10.99$ to -3.25$)$ \\
\hline Developing countries & 2 & - & $-7.89(-9.21$ to -6.58$)$ \\
\hline Case-control study design & 3 & - & $-7.79(-13.81$ to -1.79$)$ \\
\hline Other study design & 2 & - & $-6.53(-9.39$ to -3.66$)$ \\
\hline \multicolumn{4}{|l|}{ Pre-eclampsia } \\
\hline Overall & 7 & 1.79 (1.25 to 2.58$)$ & - \\
\hline Sensitivity analysis $\ddagger$ & 5 & 1.44 (0.91 to 2.30$)$ & - \\
\hline \multicolumn{4}{|l|}{ Stratified analysis*: } \\
\hline Adjusted for critical confounders & 3 & 1.51 (0.89 to 2.57 ) & - \\
\hline Unadjusted for critical confounders & 4 & 2.09 (1.26 to 3.46$)$ & - \\
\hline $25-\mathrm{OHD}<50 \mathrm{nmol} / \mathrm{L}$ & 2 & 1.27 (0.66 to 2.42$)$ & - \\
\hline $25-\mathrm{OHD}<75 \mathrm{nmol} / \mathrm{L}$ & 5 & 2.11 (1.36 to 3.27$)$ & - \\
\hline Gestational age of sampling $<16$ weeks & 5 & 1.44 (0.91 to 2.29$)$ & - \\
\hline Gestational age of sampling $>16$ weeks & 2 & 2.53 (1.41 to 4.53$)$ & - \\
\hline Case-control study design & 5 & 2.05 (1.33 to 3.14$)$ & - \\
\hline Other study design & 2 & 1.26 (0.63 to 2.53$)$ & - \\
\hline HPLC-MS assay & 3 & 1.91 (0.95 to 3.84$)$ & - \\
\hline Radioimmunoassay & 4 & 2.75 (1.14 to 2.68$)$ & - \\
\hline Overall & 5 & - & $-14.53(-22.57$ to -6.49$)$ \\
\hline \multicolumn{4}{|l|}{ Bacterial vaginosis } \\
\hline Bodnar et al, $2009^{20}$ & & $-10.6 \S(P<0.001)$ & - \\
\hline Hensel et al, $2011^{27}$ & & 2.87 ( $(1.13$ to 7.28$)$ & - \\
\hline McGuire-Davies et al, $2010^{28}$ & & $4.4 \Uparrow(P=0.02)$ & - \\
\hline \multicolumn{4}{|l|}{ Caesarean section } \\
\hline Fernandez-Alonso et al, $2011^{11}$ & & $0.83^{\star \star}(0.52$ to 1.29$)$ & - \\
\hline Scholl et al, $2012^{29}$ & & 1.99 I $(1.20$ to 3.30$)$ & - \\
\hline \multicolumn{4}{|l|}{ Small for gestational age } \\
\hline Overall & 6 & 1.85 (1.52 to 2.26$)$ & - \\
\hline 5 & 1.98 (1.60 to 2.47$)$ & - & \\
\hline
\end{tabular}

Stratified analysis* 


\section{Table 3 (continued)}

\begin{tabular}{|c|c|c|c|}
\hline Outcomes & No of studies & Pooled odds ratio $(95 \% \mathrm{Cl})$ & Pooled weighted mean difference $(95 \% \mathrm{Cl})$ (nmol/L) \\
\hline Adjusted for critical confounders & 3 & 2.05 (1.54 to 2.74$)$ & - \\
\hline Unadjusted for critical confounders & 3 & 1.68 (1.28 to 2.22$)$ & - \\
\hline $25-\mathrm{OHD}<37.5 \mathrm{nmol} / \mathrm{L}$ & 3 & 2.05 (1.54 to 2.74$)$ & - \\
\hline $25-\mathrm{OHD}<80 \mathrm{nmol} / \mathrm{L}$ & 3 & 1.69 (1.28 to 2.22$)$ & - \\
\hline Gestational age of sampling $<16$ weeks & 4 & 1.77 (1.43 to 2.19$)$ & - \\
\hline Gestational age of sampling $>16$ weeks & 2 & 2.69 (1.45 to 5.01$)$ & - \\
\hline Case-control study design & 2 & 2.16 (1.54 to 3.03$)$ & - \\
\hline Other study design & 4 & 1.70 (1.33 to 2.18$)$ & - \\
\hline Birth weight $(\mathrm{g})$ & 4 & - & $-130.92(-186.69$ to -75.14$)$ \\
\hline Birth length $(\mathrm{cm})$ & 2 & - & $-0.194(-0.65$ to 0.26$)$ \\
\hline Head circumference $(\mathrm{cm})$ & 2 & - & $-0.048(-0.34$ to 0.24$)$ \\
\hline \multicolumn{4}{|c|}{ HPLC=high performance liquid chromatography; MS=mass spectrometry. } \\
\hline \multicolumn{4}{|c|}{ †Sensitivity analysis after removing one study with unclear interquartile range. ${ }^{16}$} \\
\hline \multicolumn{4}{|c|}{$\ddagger$ Sensitivty analysis after removing two studies that reported on severe pre-elampsia. ${ }^{1923}$} \\
\hline \multicolumn{4}{|l|}{ §Geometric mean difference. } \\
\hline \multicolumn{4}{|c|}{ IAdjusted odds ratio ( $95 \%$ confidence interval). } \\
\hline \multicolumn{4}{|l|}{ **Odds ratio. } \\
\hline$\dagger †$ Sensitivity analysis after rem & & & \\
\hline
\end{tabular}




\section{Figure}

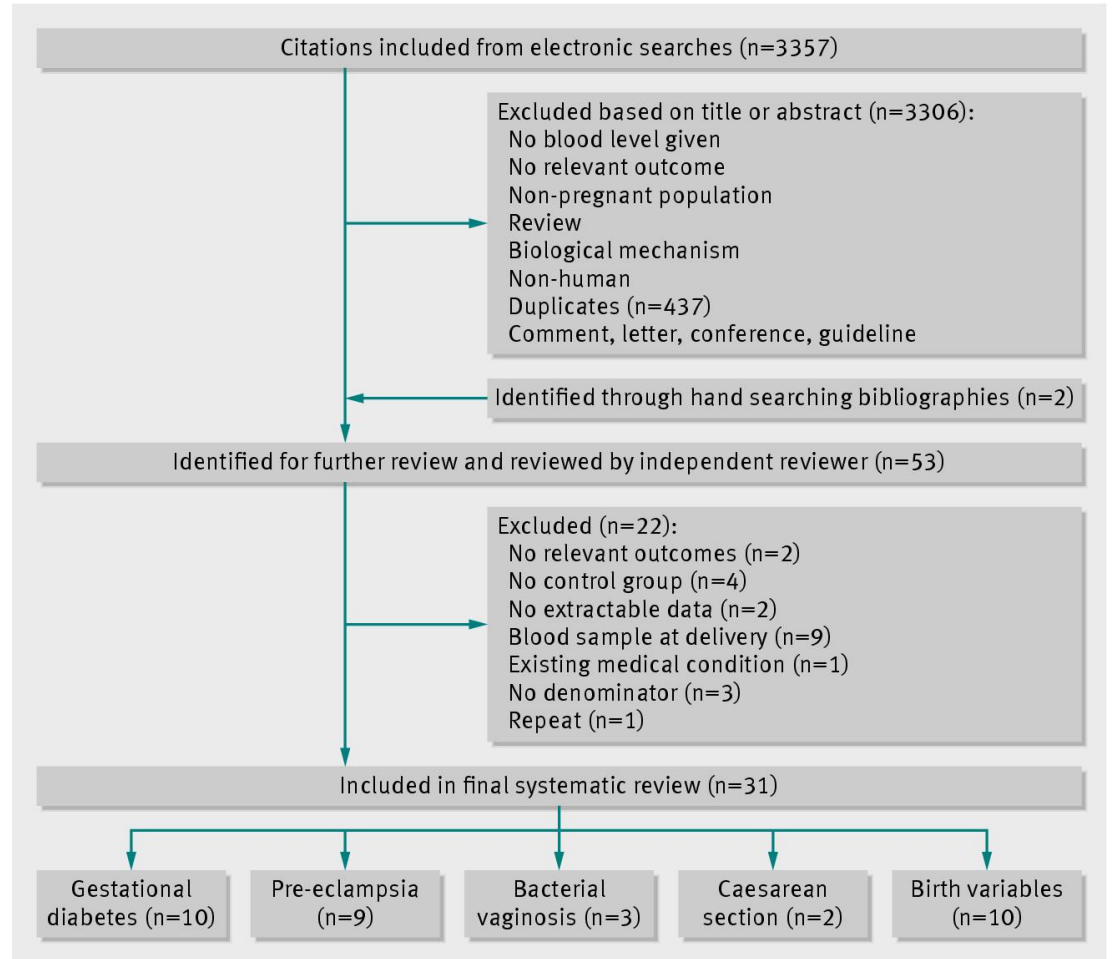

Flow of studies through review 